\title{
Variation at the Interfaces in Ibero-Romance. Catalan and Spanish Prosody and Word Order*
}

\author{
Maria del Mar Vanrell \\ Institut für Romanische Philologie - Freie Universität Berlin \\ mariadelmar.vanrell@fu-berlin.de
}

Olga Fernández Soriano

Universidad Autónoma de Madrid. Departamento de Filología Española

olga.fernandez@uam.es

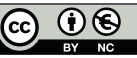

Received: August 20, 2013

Accepted: September 25, 2013

\begin{abstract}
In this study we investigate how word order interacts with prosody in the expression of sentence modality and different focus constructions in different varieties of Catalan and Spanish. We analyze a corpus obtained by means of two tasks: a) a production test designed to elicit different focus constructions by means of question-answer pairs from short picture stories and $b$ ) the Discourse Completion Task methodology. The collected data were prosodically and syntactically annotated. Our data confirm that in Catalan and Spanish the intonational prominence tends to be located in clause-final position but this is completely true only for broad focus declaratives, since the main prominence can also fall on clause-initial position in Eastern Catalan and Basque Spanish informational focus declaratives or remain in situ in both informational and contrastive focus declaratives (especially in VAL_CAT or Spanish). As for interrogative modality, an important distinction is made between languages that can present subject-verb inversion in direct questions (VAL_CAT and Spanish) and languages that cannot (Eastern Catalan). In Eastern Catalan the subject is dislocated.
\end{abstract}

Keywords: word order; prosody; focus; declarative modality; interrogative modality; dialectal variation; Catalan; Spanish.

* We are grateful to Joan Borràs-Comes for kindly providing us with the map that appears in Figure 1. Alba Chacón, Verònica Crespo-Sendra and Marianna Nadeu deserve a special mention for having participated unselfishly as narrators of the short picture stories presented in a PowerPoint slide show. We also thank participants, and people that helped us to get in contact with potential participants: Gotzon Aurrekoetxea, Mercedes Cabrera, Verònica Crespo-Sendra, Irene de la Cruz, Gorka Elordieta, Leire Gandarias, Miriam Rodríguez, Paco Vizcaíno. This research has been funded by the project FFI2011-23829/FILO awarded by the Spanish Ministry of Economy and Competitiveness. 


\section{Table of Contents}
1. Introduction
4. Discussion and conclusions
2. Methodology
References
3. Data

\section{Introduction}

The interface between prosody and word order in Ibero-Romance has not been consistently studied. A considerable amount of research has been devoted to languages like Spanish, but other languages such as Catalan are much less known. In addition, most of the work concentrates on declarative modality, particularly on the expression of focus. Although we find exceptions (such as Zubizarreta 1998 and Gabriel 2010 for Spanish), there is often a stark division between those studies that emphasize the syntactic perspective (syntactic mechanisms to mark focus: Solà 1990, Vallduví 1991, Domínguez 2002 for Catalan; Costa 2001, Gutiérrez-Bravo 2002, 2005, 2006, Domínguez 2004, Samek-Lodovici 2001, 2005 among others for Spanish) and those that draw attention to the prosodic perspective (description of the focal shape and the use of different prosodic parameters such as duration, and peak alignment/scaling: Estebas-Vilaplana 2000, Prieto in press-2014, Vanrell et al. 2013 for Catalan; de la Mota 1995, Sosa 1999, Face 2001, 2002, Hualde 2002, 2005, Gabriel 2006, 2007, Vanrell et al. 2013 for Spanish). The few studies addressing interrogative modality mainly concentrate on word order and tend to disregard dialectal variation (an exception is Prieto and Rigau 2007 for Catalan). They deal primarily with standard varieties or with varieties that present a particular characteristic (e.g., absence of subject inversion in Caribbean Spanish). Finally, as it was noted by Gabriel (2010), another difference between syntactic works on the one hand and phonological studies on the other is that they use different methodological approaches. Syntactic works make resource to introspection and grammaticality judgments, whereas phonological studies tend to use experimental methods.

This paper makes an attempt to encompass all those aspects and face the two perspectives (syntactic and prosodic), while dealing with dialectal variation and using the same controlled methodology. We investigate how word order interacts with prosody in the expression of sentence modality (declarative and interrogative modality) and different focus constructions (broad, informational and contrastive focus) in different varieties of Catalan and Spanish. For Catalan we will examine two Eastern Catalan varieties, Central Catalan and Balearic Catalan, and one Western Catalan variety, namely Valencian Catalan. As for Spanish, Castilian and Canary Islands Spanish will be explored and compared to a contact variety, the one spoken in the Basque Country.

Recent works on generative grammar have shown that the correlation between prosody and syntactic structure is not homogeneous among languages but is subject to parametric modeling (Hirschberg and Avesani 2000, de la Cruz-Pavía 2010, de la Cruz-Pavía and Elordieta submitted; see also Elordieta and Irurtzun 2012 for an overview). One aspect in which languages vary has to do with the position of the subject and its inclusion in a prosodic phrase independent of the verb (Elordieta, 
Frota and Vigário 2005). Some of the languages studied here present particular characteristics such as non dislocated subjects in Valencian Catalan interrogatives (Prieto and Cabré (eds.) 2007-2012), or OV order in Basque Spanish declaratives (Gómez Seibane 2012). It has also been claimed that non-inverted questions (which are widely attested in Caribbean varieties) are possible in Canarian Spanish. We will examine these properties aiming at isolating the crucial parameter implied and the features involved. As for declarative modality, the hypothesis that there are phonologically motivated movements will be tested, as well as the syntactic strategies that different languages resort to in «information packaging», such as (right) dislocation.

\section{Methodology}

\subsection{Participants}

The participants in our production experiment were 4 men and 10 women aged between 22 and 45 from the following locales of the two languages under study: a) Central Catalan (CENTR_CAT): 1 female speaker from Borredà and 1 female speaker from Torrelavit; Balearic Catalan (BAL_CAT): 1 female speaker from Llucmajor and 1 male speaker from Ses Salines; Valencian Catalan (VAL_CAT): 1 female speaker from Ondara and 1 male speaker from Bocairent) and b) Castilian Spanish (CAST_SPA): 2 female speakers from Madrid; Spanish of the Basque country: 2 female L1 Spanish speakers (BC_L1SPA_SPA) from Bilbao and 2 female L1 Basque speakers (BC_L1BAS_SPA) from Gernika and Zeberio respectively; Canarian Spanish (CAN_SPA): 2 male speakers from Las Palmas. See Figure 1.

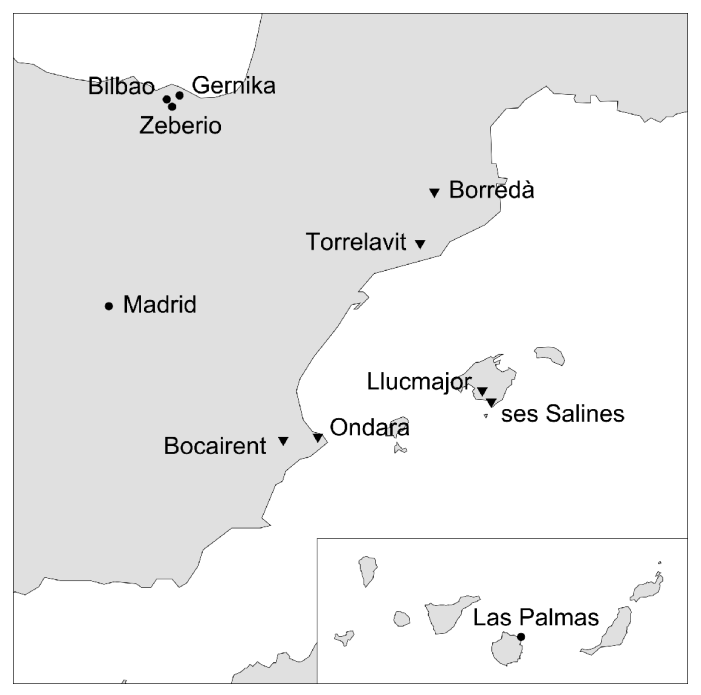

Figure 1. Map including the locales where the recordings were carried out. Inverted pyramids represent that the language of the experiments was Catalan, whereas circles represent Spanish. 


\subsection{Materials}

The corpus analyzed in this paper was obtained by means of two tasks: a) a production test designed to elicit different focus constructions (broad, narrow or informational and contrastive foci on different constituents) through of question-answer pairs from short picture stories presented in a PowerPoint slide show (Gabriel 2010) and b) the Discourse Completion Task methodology or DCT (Blum-Kulka, House and Kasper 1989, Billmyer and Varghese 2000, Félix-Brasdefer 2010).

As for the former, we had three different stories with different main characters (a girl called Maria, Snow White and a sailor). The short stories correspond to full sentences with a canonical syntactic structure $\left(\mathrm{SVO}_{1} \mathrm{O}_{2} / \text { Adjunct }\right)^{1}$ and were controlled for Embeddedness (half of the second VP-complements were arguments and the other half were adjuncts) and Focused Constituent ( $\mathrm{S}, \mathrm{V}, \mathrm{O}_{1}$ or $\mathrm{O}_{2}$ /Adjunct). Participants were asked to respond to a series of wh-questions or tag questions and were explicitly asked to use all the constituents that appeared in them. Speakers were free to use any syntactic order or strategy on the condition that they sounded natural in their native language. The stories and the subsequent questions were as follows:

(1) Blancanieves trajo las manzanas con fatiga.

Snow. White bring.PAST.3SG the apples with tiredness

(2) a. ¿Qué ha pasado?

what have.PRES.3SG happened

b. ¿Qué trajo Blancanieves con fatiga? what bring.PAST.3SG Snow. White with tiredness

c. ¿Quién trajo las manzanas con fatiga? who bring.PAST.3SG the apples with tiredness

d. Blancanieves trajo con fatiga las naranjas, ¿verdad? Snow. White bring.PAST.3SG with tiredness the oranges right

e. ¿Cómo trajo las manzanas Blancanieves? how bring.PAST.3SG the apples Snow.White

f. Trajo las manzanas con fatiga Caperucita, bring.PAST.3sG the apples with tiredness Little.Red.Riding.Hood ¿verdad? right

g. ¿Qué hizo Blancanieves con fatiga? what do.PAST.3SG Snow. White with tiredness

h. Blancanieves trajo las manzanas con vitalidad, ¿no?

Snow.White bring.PAST.3sG the apples with vitality no

1. Where $\mathrm{O}_{1}$ and $\mathrm{O}_{2}$ refer to direct or indirect object, in both orders. 
i. ¿Qué hizo Blancanieves con las manzanas? what do.PAST.3SG Snow. White with the apples

j. Blancanieves se llevó las manzanas con fatiga, ¿verdad? Snow.White REFL take.PAST.3sg the apples with tiredness right

k. Las manzanas, las trajo con fatiga

the apples them bring.PAST.3SG with tiredness

Caperucita, ¿no?

Little.Red.Riding.Hood, no

Through this method we elicited a total of 120 contours x 14 speakers to yield a total of 1680 contours.

As for the DCT, it is an inductive method in which the researcher presents the subject with a series of situations (such as «You go into a shop you have never been to before and ask the shop assistant if they sell sugar») and then asks him or her to respond accordingly. The full survey is made up of 130 situations that allowed us to obtain a wide range of interrogative contours (direct or indirect wh- and $y / n$ questions) controlling for the type of verb (copulative, transitive, unaccusative and unergative), the type of subject (nominal, pronominal or the second person formal vostè/usted in Catalan and Spanish respectively) or the degree of presupposition about the likelihood that the speaker will get a «yes» answer to his/her utterance (information- and confirmation $\mathrm{y} / \mathrm{n}$ questions and tag questions). We also controlled the behavior of «external» adverbials of the type how come, which according to Rizzi (2001) appear in a higher position in the left periphery. We elicited a total of 1820 contours ( 130 contours x 14 speakers). ${ }^{2}$

\subsection{Procedure}

Both the question-answer pairs and the short picture stories were adapted to every specific dialectal variety under study. The short picture stories were first presented both in writing and audio, whereas the set of questions about the picture stories were presented only in audio.

The descriptions of the prompt situations of the DCT were read aloud to the participants by the authors of this paper. Speakers were then asked to respond appropriately to the situations as spontaneously as possible. Questions were recorded only once but when a speech disfluency, breaks or irregularities occurred, the prompt situation was described once again at the end of the full interview session. There was a high degree of familiarity between the interviewer and the speakers. The whole set of tasks lasted approximately 70 minutes. Speakers were recorded on Zoom H4n digital audio recorder using an AKG C520 condenser microphone.

2. Readers can access the survey by clicking this link: http://optimitza.cat/mvanrell/research 


\subsection{Analysis}

Data obtained through the question-answer pairs were annotated in Praat (Boersma and Weenink 2013) for the following fields: (1) orthographic transcription, (2) syntactic strategy used by the speaker (neutral order, right or left dislocation of the non-focused material, clefting ${ }^{3}$, constituent fronting, prosodic motivated movement, etc.), (3) syntactic order, (4) type of focus (broad, informational or contrastive focus) as well as the constituent that is under focus and (5) prosodic transcription of the data in terms of pitch accents and boundary tones ${ }^{4}$ (Hualde and Prieto in press2014, Prieto et al. in press-2014). For the utterances obtained by means of the DCT methodology, the following fields were annotated: (1) orthographic transcription, (2) position of the subject (elided, right or left dislocated, postverbal or preverbal), (3) additional lexical markers such as que or oi? and (4) prosodic transcription. The annotations were collected automatically into a file in .txt format through a Praat script and then transferred to a SPSS file for purposes of subsequent statistical exploration. The data were analyzed separately depending on the methodology used to obtain them (question-answer pairs vs. DCT method). This difference in the methodology also corresponded to a difference in the modality of the materials, that is, the materials obtained through the question-answer pairs belong to the declarative modality (though with different focal structures) whereas the materials collected using the DCT are identified as interrogative modality.

\section{Data}

\subsection{Declarative modality}

Most work devoted to the interface between word order and prosody in Catalan and Spanish concentrates mainly on the expression of focus in the standard varieties (Central Catalan and Castilian Spanish). Both languages are considered to mark focus by syntactic means, although recent studies show that prosodic strategies are possible as well (Face and D'Imperio 2005, Estebas-Vilaplana 2000). Regarding these prosodic strategies, in Catalan and Spanish it is assumed that intonational prominence falls on clause-final position and that prominence shift is not an available strategy (Vallduví 1991, Zubizarreta 1998). However, it remains unclear which prosodic strategies are possible (pitch accent shape; postfocal compression; differences in alignment, duration or pitch height), under which circumstances they operate, and how they interact with syntax. Given that prominence shift is not an available strategy, alternative syntactic mechanisms are proposed in order to vary the location of prominence. For Catalan, Vallduví (1991) proposed dislocation of the nonfocal material of a sentence to ensure that elements that the speaker wishes to focalize appear in the rightmost position, whereas in Spanish, the nonfocal mate-

3. Clefting structures were discarded from the data presented in the paper.

4. Although the ToBI system was used to analyze the contours, here we will use a more descriptive system based on the trajectory associated to the nuclear syllables (last stressed syllable of a sentence) and to the edges of the tonal units. 
rial undergoes movement to a non canonical position (p-movement or prosodically motivated movement, Zubizarreta 1998). Other syntactic strategies such as focus fronting or clefting seem to be restricted to a contrastive meaning (Solà 1990 for Catalan, Zubizarreta 1998 for Spanish).

\subsubsection{Broad focus}

For broad focus our results indicate that the most extended order in all cases is $\mathrm{SVO}_{1} \mathrm{O}_{2} /$ Adjunct. There seems to be no significant contrast between unaccusative vs. transitive/unergative verbs.

From the intonational point of view, broad focus declaratives are characterized by a nuclear falling pattern. Interestingly, the phonetic shape of the nuclear configuration in Catalan broad focus declaratives differs from that of Spanish. Speakers of Catalan varieties tend to produce a drastic fall sometimes followed by a final slight rise similar to the one found in Italo-Romance varieties (Grice, Savino and Refice 1997, Savino 2012 for Bari Italian; Roseano et al. in press-2014 for Friulian; Vanrell et al. in press-2014 for Sardinian). In Spanish varieties the last fall is less drastic and has the shape of a plateau during the nuclear syllable with no or little final slight rise. Figure 2 and 3 illustrate the two different patterns. In Figure 2 a steepest fall aligned to the syllable -si- (cosina 'cousin') is observed which is followed by a final rise. Conversely, in Figure 3 we observe a sustained pitch contour along the nuclear syllable -ble- (problemas 'problems') and low final tone. This difference in the phonetic nuclear shape of broad focus sentences between Catalan and Spanish has not gone unnoticed in the literature and it was previously attested in Estebas-Vilaplana (2003a,b), Face $(2002,2004)$ and Simonet $(2009,2010,2011)$. According to Simonet (2009: 113), it could reveal «potentially-gradual differences» existing among different Hispano-Romance languages. In addition, the author presents comparative evidence that allows him to speculate that steeper falls of Majorcan Catalan could be interpreted as a conservative feature compared to the plateau found in Castilian Spanish. However, since the type of analysis performed

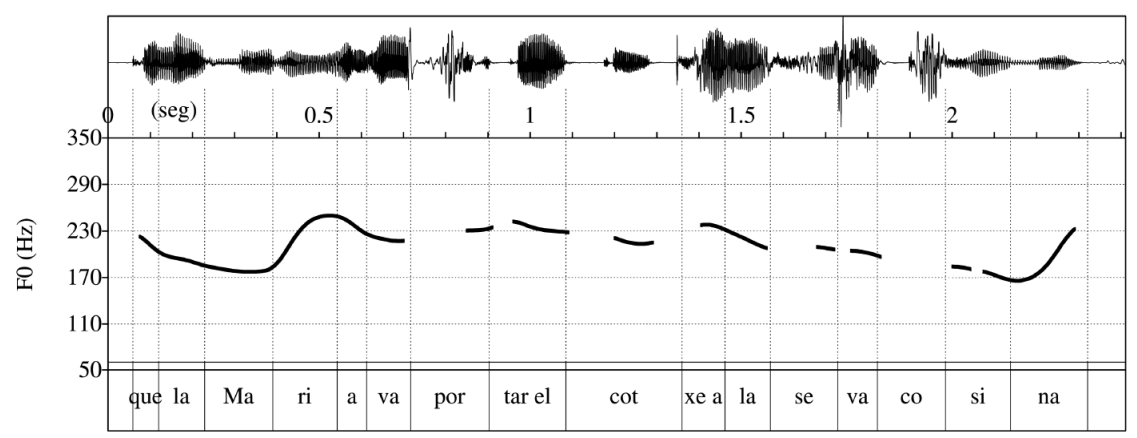

Figure 2. Waveform and F0 contour of the broad focus declarative Que la Maria va portar el cotxe a la seva cosina 'that Maria brought the car to her cousin' produced by a speaker of Central Catalan. 


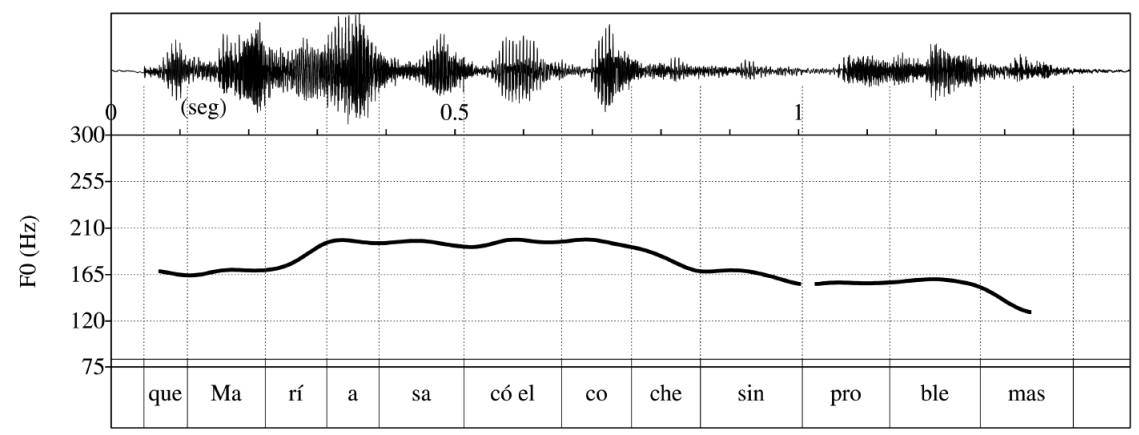

Figure 3. Waveform and F0 contour of the broad focus declarative Que María sacó el coche sin problemas 'that María took out the car without problems' produced by a speaker of Spanish of the Basque Country.

as well as the goals of our work do not allow us to go in depth into this, we will leave this issue for further research.

\subsubsection{Informational focus}

As for (narrow) informational focus, Catalan seems to present a particular behavior in the sense that the tendency is to right dislocate non focalized material (as opposed to focus in situ, p-movement or other strategies which are commonly used in Spanish). This is consistent with Vallduví's (1994) claim that the constituent(s) which belong to the «tail» part of the ground information are marked by the syntactic strategy of right dislocation (RD) in Catalan, whereas languages like English make use of the phonological strategy of stress or prominence shift (and only very marginally of RD). On the other hand, Villalba (2011) shows that while RD is a pervasive mechanism in Catalan for activation and continuation topics, Spanish makes very marginal use of this strategy. Right-dislocation does occur in Spanish (Sedano 2006) and has a topic-marking function in cases like (3):

(3) a. Lo he leído, ese libro.

ACC have.PRES.1SG read that book

$\begin{array}{lllll}\text { b. Ya } & \text { lo sé } & \text { que estás cansada. } \\ \text { already } & \text { ACC } & \text { know.PRES.1SG that be.PRES.2SG tired }\end{array}$

But the studies show that Spanish RD is restricted to «sentences, demonstratives and DPs, and to subject and object functions, and shows a sharp preference for topic activation» (Villalba 2011: 1959). Villalba's study demonstrates that Spanish resorts to realization in canonical position where Catalan uses right dislocations. ${ }^{5}$

5. For comparison this author analyzes the Spanish translation of the classical Catalan play Terra baixa by Àngel Guimerà, which represents a (colloquial spoken) register where RD is especially favored. 
Spanish canonical realizations tend to correspond to what the author calls activation topics, and to inferable and nonlocal antecedents.

So it seems clear that Catalan has a more active right periphery than Spanish. As for the parameter behind this contrast, Villalba suggests that there is a relation between the different formal mechanisms available for information packaging (Spanish, unlike Catalan, cannot fully resort to RD) and the fact that Spanish lacks a full paradigm of pronominal clitics (including oblique partitive and locative). This, according to the author, «makes Spanish RD a less regular and unambiguous mechanism for marking activation topics. In contrast, realization in canonical position is a maximally efficient mechanism: any category or function receives a similar treatment.» (2011: 1960). As a result, it seems that Spanish treats the information that Catalan encodes by means of RD as if it were new information. This would cause potential informational ambiguity between focus and canonical realization of background material that, as Ziv (1994) suggests, can be resolved by means of additional prosodic mechanisms.

Contrary to what has been said (Solà 1990 for Catalan, Zubizarreta 1998 for Spanish), in our data fronting is not restricted to contrastive focus. Thus, both in Eastern Catalan (BAL_CAT and CENTR_CAT) and in Spanish of the Basque Country (BC_L1SPA_SPA and BC_L1BAS_SPA) we find an important percentage of instances of constituent fronting (about $30 \%$ for the two varieties of Catalan and BC_L1SPA_SPA and about $15 \%$ in BC_L1BAS_SPA). See (4):
a. Què va entrar, na Maria, amb dificultat? BAL_CAT what put into.PAST.3SG PERS.ART Maria with difficulties Es cotxe va entrar na Maria amb dificultat. the car put into.PAST.3SG PERS.ART Maria with difficulties.

b. A qui va enviar la carta, el mariner?

CENTR_CAT to who send.PAST.3SG the letter the sailor)
A la dama va enviar la carta el mariner.

to the lady send.PAST.3SG the letter the sailor

c. ¿Qué le dio el marinero al viejo? BC_L1BAS_SPA what DAT give.PAST.3SG the sailor to-the old.man
La carta le dio
el marinero al viejo.
the letter DAT give.PAST.3SG the sailor to-the old.man
d. ¿Qué sacó María sin problemas? BC_L1SPA_SPA what take out.PAST.3SG María without problems

e. El coche sacó María sin problemas the car take out.PAST.3SG María without difficulties

The causes for constituent fronting in informational focus structures are difficult to determine. One could hypothesize that in Catalan it is related to a more extensive use of the sentential left periphery (as proposed by Cruschina 2011, 2012 for languages such as Sardinian and Sicilian). That arises further typological 
questions such as why Romance languages differ as to the placement of the focus as well as to the possible special meanings associated to it (Cruschina 2012). For reasons of space we will not address these questions here. In Spanish spoken in the Basque Country, the high occurrence of informational focus declaratives with fronting (compared to CAN_SPA or CAST_SPA) could be due to the influence of Basque (Urrutia 1995, Gómez Seibane 2012). However, it is important to highlight that this fronting is only found in sentences where there is one constituent under focus and never in broad focus declaratives (or sentences in which the whole sentence is the focus).

Other common strategies are focus prosodically marked in situ (in VAL_CAT, CAN_SPA, CAST_SPA and BC_L1BAS_SPA). Since VAL_CAT only has the oblique clitic corresponding to the partitive en, its behavior on a par with Spanish is somehow expected.

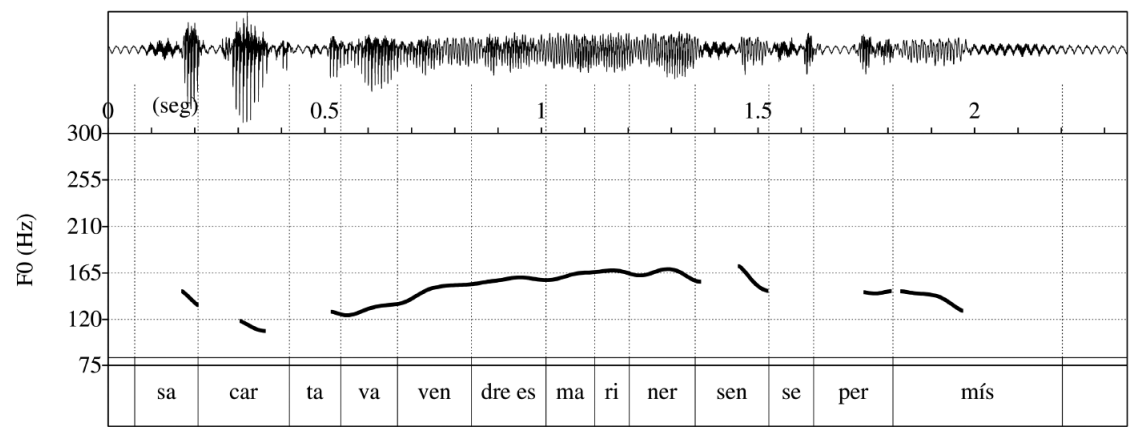

Figure 4. Waveform and F0 contour of the (narrow) informational focus declarative Sa carta va vendre es mariner sense permís 'The letter (obj), sell.PAST.3sG the sailor (subj) without permission produced by a speaker of BAL_CAT.

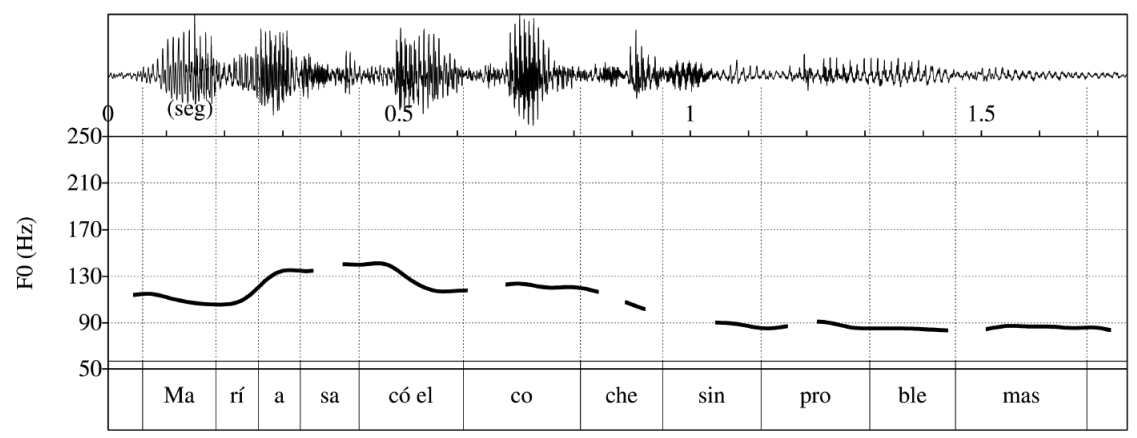

Figure 5. Waveform and F0 contour of the (narrow) informational focus declarative María sacó el coche sin problemas 'María took the car out without problems' produced by a speaker of CAN_SPA. 
As for intonation, in both Catalan and Spanish (narrow) informational focus we find an increase of occurrences of rising patterns. However, the falling patterns are still dominant. This difference in the intonational pattern is often due to the syntactic strategy used to mark the constituent under focus. Thus, whereas there is a high correlation between focus marked in situ and rising intonational patterns, other strategies such as dislocation of the non-focal material or fronting seem to select falling intonational patterns. Figure 4 shows an informational focus declarative as produced by a speaker of Balearic Catalan. As we can observe, a falling movement is associated to the syllable car- (carta 'letter') followed by a downstepped edge tone. Unlike contrastive focus, Catalan fronted constituents with an informational meaning do not display postfocal compression. Thus, as we can observe in Figure 4 , after the downstepped edge tone the contours keep rising until the right edge of the first part of the postfocal section ([es mariner] 'the sailor'), where it starts to fall until the end of the contour. Figure 5 illustrates the rising pattern (generally less common but still dominant in the Spanish varieties) as produced by a speaker of Canarian Spanish. A rising pitch accent is observed on the syllable co- (ocche 'car') followed by postfocal compression.

\subsubsection{Contrastive focus}

In our data for contrastive focus declaratives, again the distinction between languages preferring dislocation (mostly Catalan) and languages that use other strategies (fronting of the focus constituent and focus marked prosodically in situ) arises. Another interesting finding is that fronting becomes a more frequent option in CAT_VAL and SPA_CAST, languages that cannot resort to this strategy for informational focus. Coming back to the issue of whether contrast is necessary for the focus constituent to be moved to the left periphery, we observe that the varieties studied here divide in two groups: on the one hand, we have languages for which contrast is not essential (Eastern Catalan and Basque Spanish) and, on the other hand, languages for which contrast is an indispensable condition (VAL_CAT and CAST_SPA). CAN_SPA is outside this classification, since it seems to disprefer focus fronting for any of the two meanings.

Our results support the proposal made in Face and d'Imperio (2005), which show that the word order versus intonation focal typology is too rigid and that a revised typology of a continuum of word order and intonation in marking focus should be proposed. According to them, this typology allows «for a distinction between word order languages and intonation languages, but also for distinction between languages that use both mechanisms of focal markings to different degrees» (Face and D'Imperio 2005: 274). This can be led to the field of dialectal variation. Thus, also different varieties of the same language can be on different points of this continuum or use both mechanisms to a different degree.

Interestingly, languages which move informational focus divide into two tendencies for contrastive focus: BAL_CAT and CENTR_CAT make crucial use of right dislocation (see (5) and (6)), whereas BC_L1SPA_SPA and BC_L1SPA_SPA have focus in situ (as seen in (7) and (8)). 
(5) No, li va dur

ses pomes, a(n) es príncep, na

Blancaneu

$B A L \_C A T$

no DAT bring.PAST.3SG the apples to the príncep PERS.ART Snow.White

(6)

No, li va portar el cotxe, la

Maria, al seu veí

CENTR_CAT

no DAT bring.PAST.3SG the car PERS.ART Maria to-the her neighbor

(7) No, María llevó

el coche a su prima

no María bring.PAST.3SG the car to her cousin

$B C \_L 1 B A S \_S P A$

(8) No, María sacó

EL COCHE sin problemas BC_L1SPA_SPA

no María take out.PAST.3SG the car without problems

With respect to intonation, in both Catalan and Spanish contrastive focus declaratives, rising nuclear configurations experiment a drastic increase (from $40 \%$ of occurrences in informational focus declaratives to $71 \%$ of occurrences in contrastive focus). This increase in the percentage of appearance of rising contours correlates (though not exclusively) with an increment in the use of constituent fronting as a marker of contrastive focus. As has been described in the literature, contrastive focus usually precedes postfocal compression (Xu 1999, Xu et al. 2012, Vanrell et al. 2013). However, it is important to note that although postfocal reduction is a very significant mechanism to mark contrast in both languages studied here, it is not a prerequisite. In a previous study conducted by Vanrell et al. (2011) on Catalan, Italian and Spanish and with the gating paradigm, it was shown that hearers have no need to hear the postfocal region to distinguish between two focal conditions (contrastive vs. non-contrastive). Thus, they were able to recognize fairly well the presumed contrastiveness of the tonal accent just by listening to the portion going from the beginning of the sentence to three quarters of the way through the syllable bearing the contrastive accent. Figure 6 shows an example of a contrastive focus declarative produced by a speaker of VAL_CAT. A rising tone is associated to the syllable -si- (cosina 'cousin') and then followed by a falling final tone and postfocal compression. Figure 7 displays the same intonational pattern as produced by a speaker of CAST_SPA.

To sum up, our results confirm that in Catalan and Spanish the intonational prominence tends to be located in clause-final position but this is completely true only for broad focus declaratives, since the main prominence can also fall on clause-initial position in Eastern Catalan and Basque Spanish informational focus declaratives or remain in situ in both informational and contrastive focus declaratives (especially in VAL_CAT or Spanish). Thus, our data seem to support the claim defended in Gabriel (2010: 189): «The mechanism of syntactic focus marking is governed by strict rules to a lesser degree than suggested in much of the literature» and we could also add that it is subject to dialectal variation. 


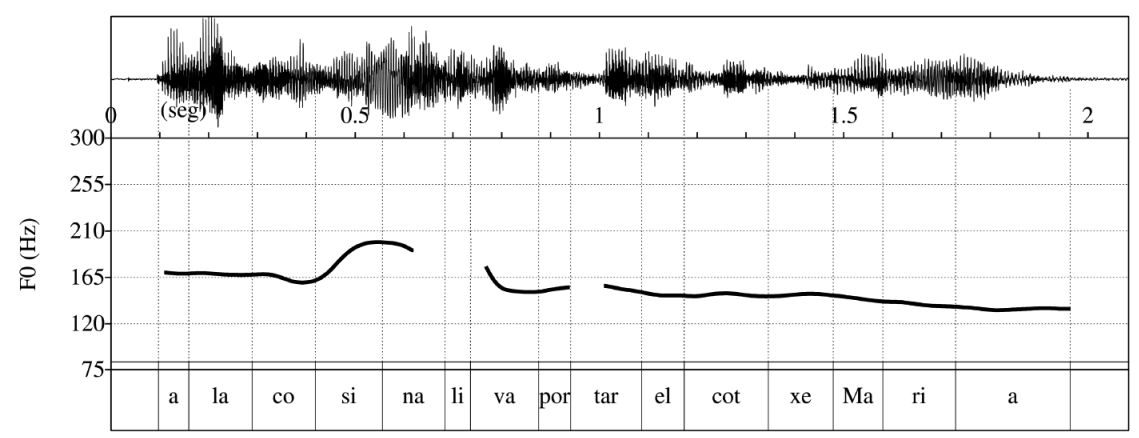

Figure 6. Waveform and F0 contour of the contrastive focus declarative $A$ la cosina li va portar el cotxe Maria 'to the cousin DAT bring.PAST.3sG the car Maria (subj)' produced by a speaker of VAL_CAT.

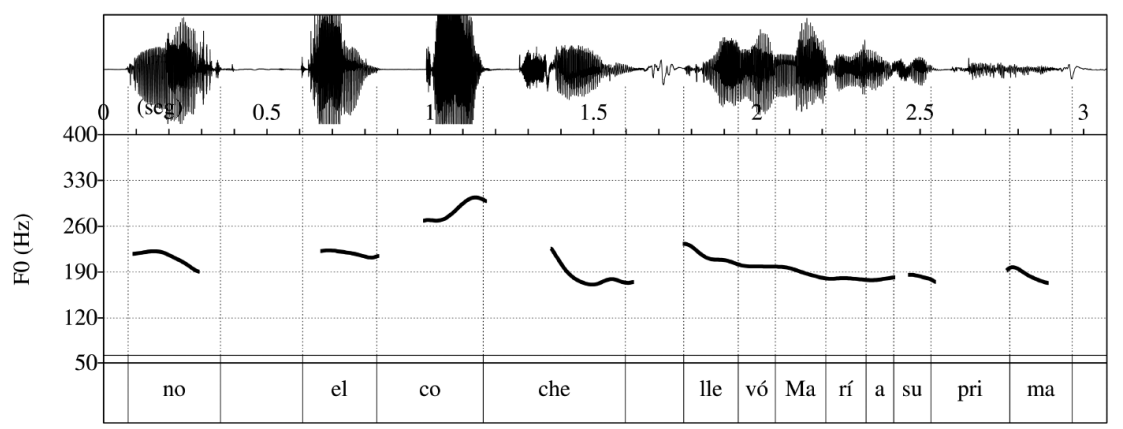

Figure 7. Waveform and F0 contour of the contrastive focus declarative No, el coche llevó María a su prima 'no, the car (obj) bring.PAST.3sG María (subj) to her cousin' produced by a speaker of CAST_SPA.

Regarding the discussion about the canonical order in Catalan (SVO vs. VOS: Solà 1992, Vallduví 1993, Rosselló 2002, Hernanz 2002, López 2003) or Spanish (SVO vs. VSO: Suñer 1982, Groos and Bok-Benema 1986, Hernanz and Brucart 1987, Fernández-Soriano 1993, Demonte 1994, Zubizarreta 1998), our data reveal that a) postverbal subjects in Catalan informational or contrastive focus declaratives are marginal and always subject to the realization of the objects as a clitic (i.e., No, la hi va donar el mariner, la carta, al vell 'No, ACC DAT give.PAST.3SG the sailor (subj), the letter (obj), to.the old.man' vs. ?No, va donar la carta al vell el mariner) whereas they are more common in Spanish (i.e., Se llevó las manzanas sin permiso Blancanieves 'REFL take.PAST.3SG the apples without permission Snow.White (subj)') and $b$ ) we do not find any instance of VSO order neither in Spanish nor in Catalan.

Figures 8 and 9 summarize the more frequent syntactic and prosodic strategies found for each language variety and focus structure (informational and contrastive focus). 


\begin{tabular}{|c|c|c|c|c|}
\hline \multirow{2}{*}{$\begin{array}{l}\text { Informational focus } \\
\text { Language varieties }\end{array}$} & \multicolumn{2}{|c|}{ More frequent option } & \multicolumn{2}{|c|}{ Second more frequent option } \\
\hline & syntax & prosody & syntax & prosody \\
\hline BAL_CAT & fronting & & $\mathrm{RD}$ & \\
\hline CENTR_CAT & $\mathrm{RD}$ & & fronting & \\
\hline VAL_CAT & LD & & $\mathrm{RD}$ & \\
\hline CAN_SPA & focus in situ & & LD & \\
\hline CAST_SPA & focus in situ & & p-movement & \\
\hline BC_L1BAS_SPA & focus in situ & & fronting & \\
\hline BC_L1SPA_SPA & fronting & & fronting/focus in situ & \\
\hline
\end{tabular}

Figure 8. Main syntactic and prosodic strategies used to mark informational focus for each language variety under study. Boxes shaded in dark grey indicate the tonal movement associated to the nuclear stressed syllable whereas boxes shaded in light grey indicate the tonal movement aligned with the postnuclear syllables.

\subsection{Interrogative modality}

The word order-prosody interface in Catalan and Spanish questions has not been examined in depth, especially when applied to dialectal variation. For Central Catalan, Rigau (2002) shows that in the interrogative modality the subject appears in the sentence periphery, both in yes-no questions and in wh-questions. Spanish data analyzed by Escandell (1999) indicate that word order in Castilian Spanish yes-no questions is free although VS order seems to be the unmarked order compared to SV. Wh-questions in Castilian Spanish typically show wh-movement to the left periphery of the sentence and subject inversion.

\subsubsection{Wh-questions}

From our data we can draw the following generalizations. For root wh-questions, a clear-cut partition shows up between BAL_CAT and CENTR_CAT on one side and VAL_CAT and Spanish on the other. The former make crucial use of the right dislo- 


\begin{tabular}{|c|c|c|c|c|}
\hline \multirow{2}{*}{$\begin{array}{l}\text { Contrastive focus } \\
\text { Language varieties }\end{array}$} & \multicolumn{2}{|c|}{ More frequent option } & \multicolumn{2}{|c|}{ Second more frequent option } \\
\hline & syntax & prosody & syntax & prosody \\
\hline BAL_CAT & $\mathrm{RD}$ & & fronting/RD & \\
\hline CENTR_CAT & $\mathrm{RD}$ & & $\mathrm{RD}$ & \\
\hline VAL_CAT & fronting & & LD & \\
\hline CAN_SPA & focus in situ & & LD & \\
\hline CAST_SPA & focus in situ & & fronting & \\
\hline BC_L1BAS_SPA & focus in situ & & p-movement & \\
\hline BC_L1SPA_SPA & focus in situ & & fronting & \\
\hline
\end{tabular}

Figure 9. Main syntactic and prosodic strategies used to mark contrastive focus for each language variety under study. Boxes shaded in dark grey indicate the tonal movement associated to the nuclear stressed syllable whereas boxes shaded in light grey indicate the tonal movement aligned with the postnuclear syllables.

cation strategy whereas the latter clearly do not. The result is that examples such as (9) are common in Balear and Central Catalan and those like (10) are the norm in Spanish as well as in the variety of Catalan spoken in Valencia.

(9) I quan fa feina, n'Aina? and when make.PRES.3SG work PERS.ART-Aina

$B A L \_C A T$

(10) a. ¿Dónde nació

Ana? where be.born.PAST.3sg Ana

$C A S T \_S P A$

b. Què volia

el fill de la veïna?

$V A L \_C A T$ what want.PAST.3SG the son of the neighbor

Our data also show that the possibilities of appearing in preverbal position increase in the case of first and second person pronominal subjects, that is, sen- 
tences like (11) are possible, whereas sentences like (12) are more marginal, though still possible.

(11) a
I jo quan faig
feina?
$B A L C A T$
and I when make.PRES.1SG work

b. Oye, ¿tú cuándo trabajas?

listen.IMP.2SG you when work.PRES.2sg

CAN_SPA

(12) a. Quan treballo, jo?

when work.PRES.1SG I

b. ¿A quién le entregué yo el paquete?

to who DAT deliver.PAST.1SG I the package

CENTR_CAT

CAN_SPA

Our data reveal that in Spanish the second person formal form usted, which agrees in $3^{\text {rd }}$ person with the verb, appears more frequently in postverbal position (see (13)) than first and non formal second person pronominal subjects. In Catalan it tends to be dislocated but it can also appear in preverbal position (see (14)).
. ¿A quién entregó
usted
el paquete?
CAN_SPA to who
b. ¿Dónde nació usted?
where be born.PAST2SG. 2SG.FORMAL
BC_L1BAS_SPA
feina, vostè?
$B A L \_C A T$ when make.PRES.3SG work 2SG.FORMAL
CENTR_CAT
b. Vostè què volia?
2SG.FORMAL what want.PAST.3SG

(14) a. Quan fa

This form has been shown to have a special behavior in standard Spanish. In particular it has been observed, on the one hand, that the explicit realization of usted(es) is much more frequent than that of the rest of pronominal (strong) pronouns. ${ }^{6}$ This has been related both to pragmatic and grammatical factors (see Fernández Ramírez 1951, Keniston 1937, Rosengren 1994 and Enríquez 1984). It is also important to note that the presence of the form usted does not correlate with any particular (contrastive/distinctive) interpretation, contrary to all the other pronominal strong forms. ${ }^{7}$ A clear (and extreme) example is provided by imperative forms, which generally does not allow for an explicit (second person pronoun) subject unless it carries a strong contrastive value (and receives contrastive strength):

6. This is at least the situation in European Spanish. For the dialects spoken in Latin America, as Kany (1951) already notes, the form usted is regularly omitted in the dialects in which subject and object strong pronouns are generally dropped. Kany suggests that this is due to the lack of coexistence with the familiar counterpart (at least in the plural).

7. Sánchez López (1993) presents a detailed description and a tentative analysis of the facts. See also Fernández Soriano (1999). 
(15)
b. Dígame usted qué desea say.IMP.3SG 2SG.FORMAL what wish.PRES.3SG qué deseas).
what wish. PRES.2SG

But most interestingly, this «neutral» interpretation of usted obtains in restricted positions (where full DP's -pronominal or not- are excluded). In particular subject usted(es) is not contrastive or focalized when it appears in «sentence second position», that is, immediately after the finite verb or auxiliary verb, both in declaratives and interrogatives:

(16) a. Habrá usted notado la diferencia. have.FUT.3SG 2SG.FORMAL noticed the difference (vs. *Habrás tú notado la diferencia.) have.FUT.2SG you noticed the difference

b. Se irá usted acostumbrando a ello. REFL go.FUT.3SG 2SG.FORMAL getting used to it (vs. *Te irás tú acostumbrando a ello.) REFL go.FUT.2SG you getting used to it
c. ¿Puede usted verlo? (vs. ??¿Puedes tú can.PRES.3SG 2SG.FORMAL see.INF-ACC can.PRES.2SG you verlo?)
see.INF-ACC

It is also important to note that in this case, usted is not incompatible with a dislocated explicit subject. Again this is impossible for the rest of tonic pronouns:

(17) a. (En cuanto a los clientes), están ustedes invitados. in respect to the customers be.PRES.3PL 2PL.FORMAL invited (vs. *estáis vosotros invitados.) be.PRES.2PL you invited

b. Los médicos, son ustedes un colectivo muy admirable. the doctors be.PRES.3PL 2PL.FORMAL a collective very admirable (vs.*sois vosotros un colectivo muy admirable.) be.PRES.2PL you a collective very admirable

The reason for this particular behavior has been related to a mismatch between the features of usted (which is a second person, formal) and the features in INFL (third person). Our data also indicate that there is a specific position for this form inside IP.

As for the position of the subject in wh-interrogatives, in traditional dialectal studies it has been claimed that Spanish spoken in the Canary Island follow the 
tendency observed for Caribbean varieties to lack subject inversion. Lipski, for example, states that: «Non-inverted questions of the sort ¿qué tú quieres? 'what do you want?' are usual in Cuban, Puerto Rican and Dominican Spanish, somewhat less so in Venezuelan and Panamanian Spanish, and quite uncommon in the remainder of Latin America, as well as being extremely rare in the Iberian Peninsula. In the Canary Islands, non-inverted questions are not as common as in the Caribbean, but among older speakers in rural regions, the frequency rises appreciably, indicating a higher rate of usage in the past, when the Canary influence on Caribbean Spanish was strongest. [...] The tight concentration of non-inverted questions in Latin American Spanish, limited to the Antilles and a few coastal Caribbean regions, correlates neatly with Canary Island influence, and also with recent Galician arrivals.» (Lipski: personal webpage).

Nevertheless, our results show no cases of interrogatives without inversion in CAN_SPA.

As for intonation in interrogative modality, first we would like to highlight the crucial role of prosody in marking whether the subject is dislocated or not. Each dislocated element constitutes a tonal unit which is independent of the core sentence. Hence, an intonational contour made of a core sentence and two dislocated elements (i.e., Vindrà, la Maria, demà? 'Will come, Maria, tomorrow?') is produced with three different tonal units. Most instances of dislocated subjects in our data are right dislocations. Right dislocated elements reproduce the intonational pattern of the core sentence but with some variation depending on whether the intonational contour is rising or falling. When the core sentence is characterized by a rising intonational pattern, the dislocated element replicates the same intonational pattern but with a higher final pitch (as can be observed in Figure 10). By contrast, when a falling contour is found, the intonation of the right dislocated element is very similar to that of postfocal material (see section 3.1.3), that is, the intonational pattern is falling too but produced in a compressed pitch range (seen in Figure 11).

Generally speaking, wh-questions in our data can be grouped into two different intonational patterns, depending on the pitch tonal event associated with the nuclear

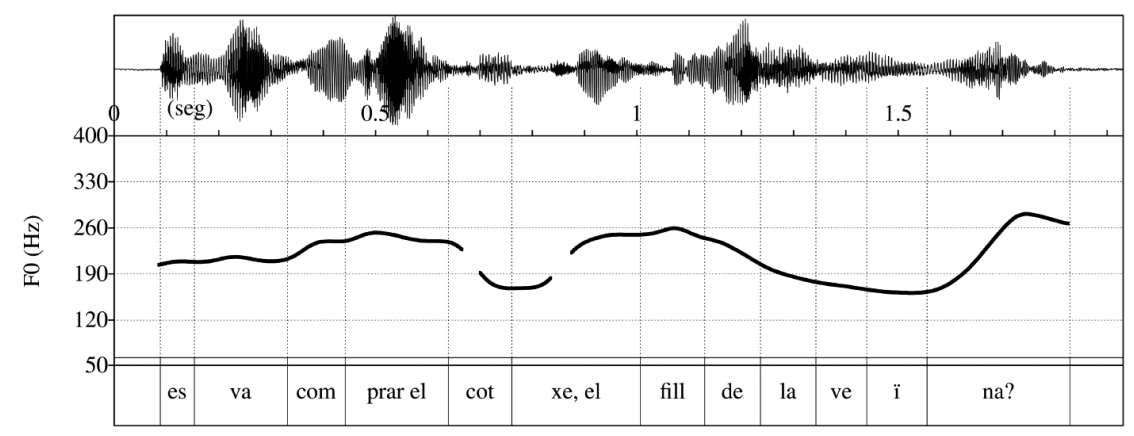

Figure 10. Waveform and F0 contour of the yes-no question with the subjet right dislocated after the coma Es va comprar el cotxe, el fill de la veïna? 'Self bought the car, the son of the neighbor' produced by a speaker of CENTR_CAT. 


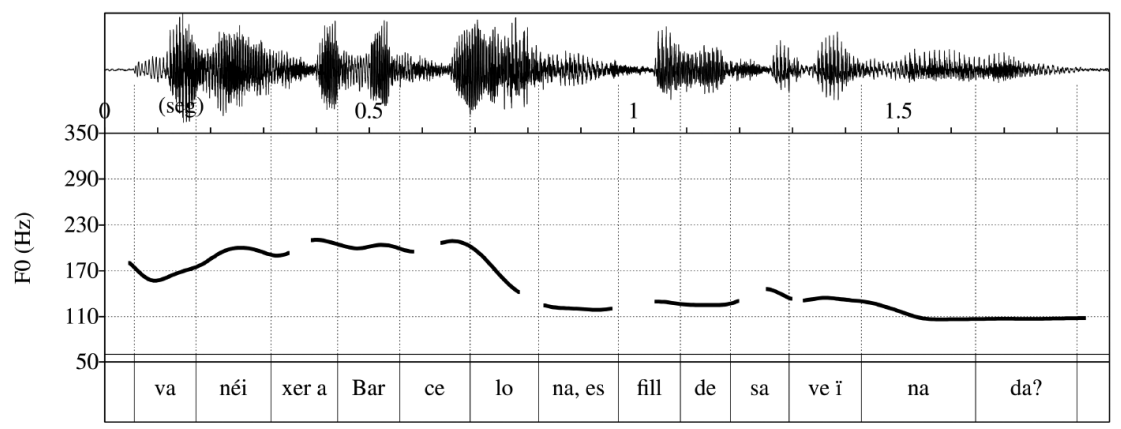

Figure 11. Waveform and F0 contour of the yes-no question with the subject right dislocated Va néixer a Barcelona, es fill de sa veïnada? 'Was he born in Barcelona, the son of the neighbor?' produced by a speaker of BAL_CAT.

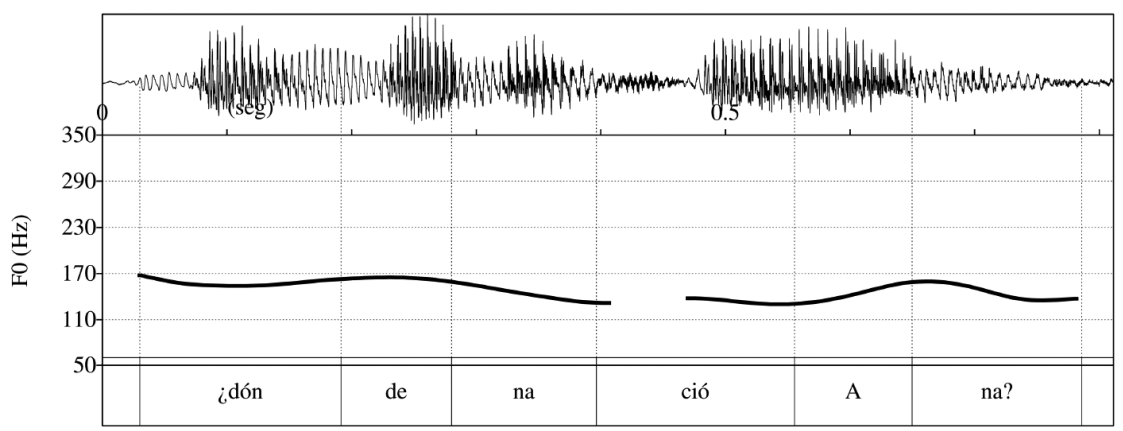

Figure 12. Waveform and F0 contour of the wh-question ¿Dónde nació Ana? 'Where was Ana born?' produced by a speaker of CAN_SPA.

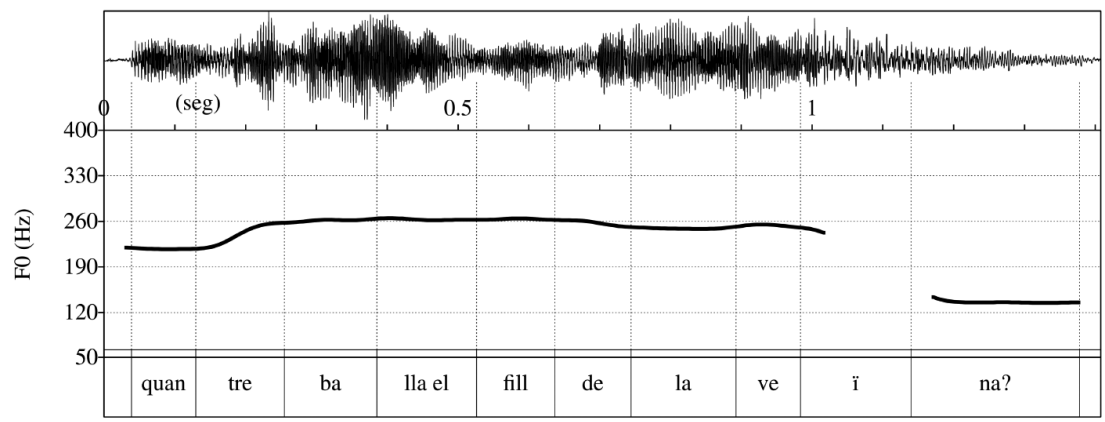

Figure 13. Waveform and F0 contour of the wh-question Quan treballa el fill de la veïna? 'When does the son of the neighbor work?' produced by a speaker of VAL_CAT. 
syllable: high and falling/low. Whereas CENTR_CAT and CAN_SPA follow the first pattern, the rest of varieties are characterized by the second pattern. The tonal trajectory following the nuclear syllable tends to be low but in BAL_CAT and CAST_SPA can also be rising. Figure 12 illustrates a wh-question produced by a speaker of CAN_SPA. A high tone during the nuclear syllable $(A$ - from $\underline{A} n a)$ can be perceived, followed by a final fall. Figure 13 displays a wh-question produced by a speaker of VAL_CAN. The nuclear syllable -ï- (veïna 'neighbor') is realized with a falling tone and the postnuclear tonal movement is low. The more frequent presence of falling nuclear configurations in wh-questions could be due to the fact that they are formally marked by a wh-word and therefore they do not need to be marked intonationally.

\subsubsection{Yes-no questions}

For root yes/no questions, again BAL_CAT and CENTR_CAT tend to right dislocate the subject, as in (18); in VAL_CAT and CAN_SPA, the verb does not have to move so we find preverbal subjects as in (19). Our data also indicate that in CAST_SPA, BC_L1EUSK_SPA and BC_L1SPA_SPA, the subject is postverbal in most of the cases, as in (20). Interestingly, $1^{\text {st }}$ and $2^{\text {nd }}$ person pronominal subjects are more common in preverbal position, as in (21). Again, it is interesting to isolate the behavior of the form usted. As was seen for wh-interrogatives, this pronominal forms does not behave as the rest of personal pronouns in Spanish, neither as a full DP (see Fernández Soriano 1999). In our cases it appears dislocated in BAL_CAT and CENTR_CAT, and tends to be inverted in the rest of the varieties analyzed, see (22):

(20)

(18) a. Treballa fins tard, el fill de la veïna? work.PRES.3SG until late the son of the neighbor

b. Fa feina fins tard, es fill de sa veïnada? work.PRES.3sG until late the son of the neighbor

(19) a. Maria és francesa?

Maria is French

b. ¿La mujer de Juan es francesa? the wife of Juan is French
a. ¿Nació
el hijo de la vecina en Madrid? be born.PAST.3SG the son of the neighbor in Madrid
b. ¿Compró el hijo de la vecina el coche? buy.PAST.3SG the son of the neighbor the car
BC_L1EUSK_SPA

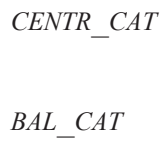

BAL_CAT

You buy.PAST.3SG a car

b. ¿Tú eres francés?

CAST_SPA you are French 
(22) a. Va néixer

a Barcelona, vostè?

CENTR_CAT be born.PAST.3SG in Barcelona 2SG.FORMAL
b. ¿Compró
usted
el coche? comprar.PAST.3SG 2SG.FORMAL the car
BC_L1BAS_SPA

If we now go to embedded questions, our data show a general tendency to have the subject in final position (VOS order) in wh-questions (see (23)) and to have preverbal subjects in yes/no questions (as in (24)). ${ }^{8}$
(23) a. Es meu amic me demana a mem quan compraria BAL_CAT the my friend DAT ask.PRES.3SG PRT when buy.COND.3SG es jersei es fill de sa veïnada. the pullover the son of the neighbor
b. Mi amigo me ha preguntado a quién le ha dicho algo CAST_SPA my friend DAT has asked to who DAT has said something el amigo de María.
the friend of María

(24) a. El meu amic m'ha preguntat si Joan va comprar el cotxe.
VAL_CAT the my friend DAT-has asked whether Joan buy.PAST.3SG the car

b. Mi amigo me ha preguntado si Juan nació CAST_SPA my friend DAT has asked whether Juan be born.PAST.3SG en Madrid. in Madrid

It has been observed that in Caribbean Spanish the use of explicit pronouns is much more widespread than in Standard Spanish. Alba (1982), for example, notes that the second person pronoun $t u$ is almost obligatory in the Spanish variety spoken in Santiago (Dominican Republic). This phenomenon has been related to influence of English and to the weakening of verbal inflection as a result of the loss of final $-S$, and the subsequent convergence of the three singular forms of the verb, and nasal reduction (Hochberg 1986). The deletion of final $-s$ is also present in Peninsular Spanish dialects such as Andalusian or Canarian Spanish. As in the case of Caribbean Spanish, this deletion makes that second and third persons singular become identical in most of forms. Ranson (1991) carried out an analysis of contextual personal markers aiming to test whether subject pronouns in Andalusian Spanish were used to resolve the ambiguity in verb forms. Contrary to what was found by Hochberg (1986) with respect to Puerto Rican Spanish, the results reveal that Andalusian Spanish shows no increased use of subject pronouns

8. Since dislocation and focused subjects are less likely to appear in these contexts, the most general tendency with pronominal subjects is omission, again with the exception of usted. 
when verb endings are ambiguous and that other factors such as contextual markers have an important effect on indicating person. Yet, according to Ranson (1991), resolving ambiguity in the verb form is not the only function of subject pronouns in Spanish (Bentivoglio 1983, D’Introno 1989, Silva-Corvalán 1982).

In any case, against traditional belief (Lipski and others), in our data the percentage of pronominal subject drop is not particularly low in en CAN_SPA. Nevertheless, the participants explicitly claimed to have the impression that the second person pronoun tú was much more frequent in their dialect than in other varieties of Spanish.

In none of the cases, a clear correlation is obtained between subject «heaviness» and subject position nor between degree of presupposition and subject position. The exception is tag questions with a high degree of presupposition in which the subject tend to occupy preverbal position (with the exception of usted in Spanish that tends to be postponed).

As in the case of wh-questions, yes-no questions in our data can be grouped into two categories according to the tone associated to the nuclear syllable: high (Spanish varieties) and low/falling (Catalan varieties). The final tonal trajectory can also be rising (CENTR_CAT and VAL_CAT) or falling/low (BAL_CAT for Catalan and Spanish varieties). One could hypothesize that the variation found regarding the nuclear tone is related to language variation (Catalan vs. Spanish) whereas the tonal variation located at the final stretch of the contour is related to the syntactic marking of modality. In other words, languages marking interrogative modality by subject inversion or dislocation do not need to resort to rising final intonation, but languages not obligatorily using subject inversion or dislocation (such as VAL_CAT and CAN_SPA) have rising final tones available in their intonational grammars. This is just a generalization and we have to acknowledge that there are languages such as CENTR_CAT or CAN_SPA that display mixed patterns (falling or rising). Figure 14 shows an instance of a yes-no question produced by a CENTR_CAT speaker characterized by a low-rising nuclear configuration. In Figure 15, the high-falling pattern found in CAST_SPA is illustrated.

To summarize, Figure 16 shows the different syntactic and prosodic strategies that arise for different question types (wh- and yes-no questions) and different language varieties.

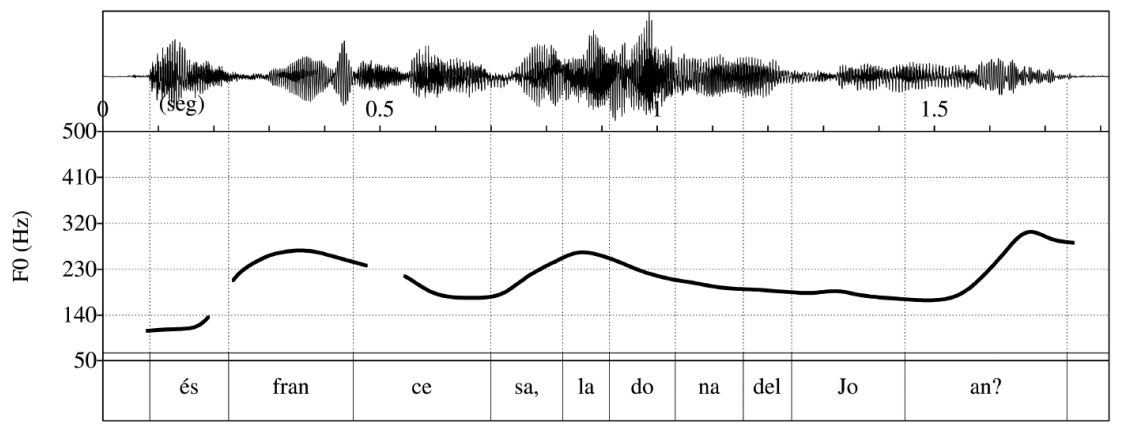

Figure 14. Waveform and F0 contour of the yes-no question with right dislocation of the subject És francesa, la dona del Joan? 'Is she French, Joan's wife?' produced by a speaker of CENTR_CAT. 


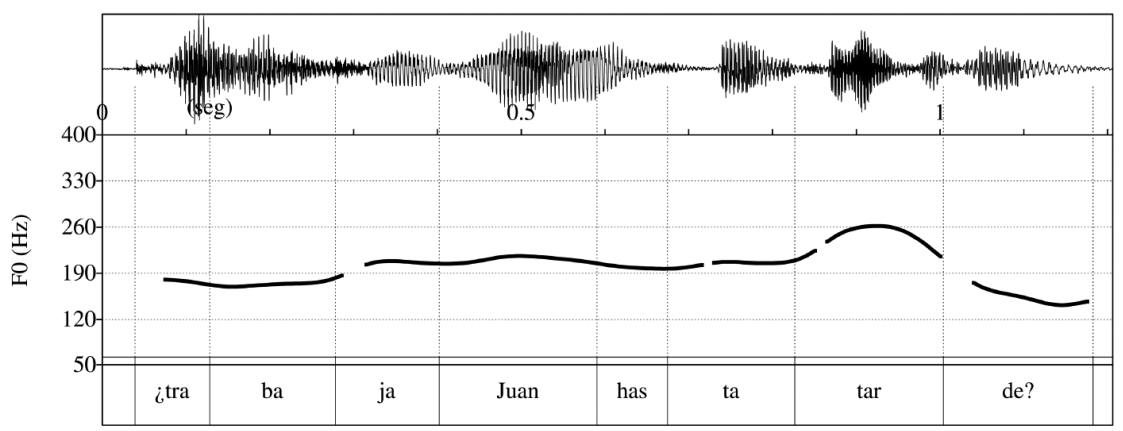

Figure 15. Waveform and F0 contour of the yes-no question ¿Trabaja Juan hasta tarde? 'Does Juan work until late?' produced by a speaker of CAST_SPA.

\begin{tabular}{|c|c|c|c|c|}
\hline \multirow{2}{*}{$\begin{array}{c}\text { Language } \\
\text { varieties }\end{array}$} & \multicolumn{2}{|c|}{ Wh-questions } & \multicolumn{2}{|c|}{ Yes-no questions } \\
\hline & syntax & prosody & syntax & prosody \\
\hline BAL_CAT & $\begin{array}{c}\text { subject } \\
\text { dislocation }\end{array}$ & & $\begin{array}{c}\text { subject } \\
\text { dislocation }\end{array}$ & \\
\hline CENTR_CAT & $\begin{array}{c}\text { subject } \\
\text { dislocation }\end{array}$ & & $\begin{array}{c}\text { subject } \\
\text { dislocation }\end{array}$ & \\
\hline VAL_CAT & $\begin{array}{l}\text { subject } \\
\text { inversion }\end{array}$ & & $\begin{array}{l}\text { preverbal } \\
\text { subject }\end{array}$ & \\
\hline CAN_SPA & $\begin{array}{l}\text { subject } \\
\text { inversion }\end{array}$ & & $\begin{array}{l}\text { preverbal } \\
\text { subject }\end{array}$ & \\
\hline CAST_SPA & $\begin{array}{l}\text { subject } \\
\text { inversion }\end{array}$ & & $\begin{array}{l}\text { postverbal } \\
\text { subject }\end{array}$ & \\
\hline BC_L1BAS_SPA & $\begin{array}{l}\text { subject } \\
\text { inversion }\end{array}$ & & $\begin{array}{c}\text { postverbal } \\
\text { subject }\end{array}$ & \\
\hline BC_L1SPA_SPA & $\begin{array}{l}\text { subject } \\
\text { inversion }\end{array}$ & & $\begin{array}{c}\text { postverbal } \\
\text { subject }\end{array}$ & \\
\hline
\end{tabular}

Figure 16. Main syntactic and prosodic strategies used to mark wh-questions and yes-no questions for each language variety under study. Boxes shaded in dark grey indicate the tonal movement associated to the nuclear stress syllable whereas boxes shaded in light grey indicate the tonal movement aligned with the postnuclear syllables. 


\subsubsection{The left periphery and the node INT. «External» questions}

As Rizzi (2001) notes, in Italian some wh-operators like perché 'why' and other higher adverbials, like come mai 'how come', behave differently from ordinary ones in the sense that they do not require subject inversion. Rizzi provides the examples in (25):

(25) a. Perché Gianni è venuto? why Gianni is come

b. Come mai Gianni è partito? how come Gianni is left

They are also consistent with short adverbials preceding the inflected verb as in (26). Clearly, these elements do not trigger I to C movement:

(26) a. Perché (i tuoi amici) già hanno finito il lavoro? why the your friends already have.PRES.3PL finished the work

b. Come mai (voi) già siete tornati a Milano? how come you already be.PRES.2PL come back to Milan

Acording to Rizzi (2001), these adverbs occupy the specifier position of an extra peripheral node, INT. «The Spec of INT is presumably filled by a null operator in main and embedded yes-no questions, so it may be specialized for other operator-like elements which can be base generated there. Perhaps, INT selects in its Spec clausal operators, which are first merged there [...]. If INT is intrinsically endowed with the feature wh, no inversion is needed». These adverbials can co-occur with focus, as seen in (27):

(27) a. Perché QUESTO avremmo dovuto dirgli, non qualcos'altro? why this have.COND.1PL must.PP say.INF-DAT not whatever

b. Come mai IL MIO LIBRO gli ha dato, non il tuo? how come the my book DAT has given not the yours

In our data, the same situation is obtained both in Spanish and in Catalan. Although it is not fully systematic, speakers show a preference for preverbal subjects in these cases:

(28) a. Per què li ha dit això, n'Aina, a(n) en Joan? BAL_CAT why DAT has said this PERS.ART-Aina, to PERS.ART Joan

(vs. Però $\mathrm{i}$ ara perquè n'Aina ha dit això a en

but and now how come PERS.ART-Aina has said that to PERS.ART Joan?

Joan

b. ¿Por qué trabaja Ana tanto?

why work.PRES.3sG Ana so.much

(vs. ¿Por qué Ana trabaja tanto?)

how come Ana work.PRES.3SG so.much 


\section{Discussion and conclusions}

This study set out to investigate how word order interacts with prosody in the expression of sentence modality and different focus structures in Ibero-Romance using the same controlled methodology. To this end, two production experiments were designed aiming to elicit different focus constructions (question-answer pairs from short picture stories presented in a PowerPoint slide show) and different question types (DCT methodology). The collected data were prosodically and syntactically (syntactic strategies used to mark focus, subject position, syntactic order of the constituents) annotated with Praat (Boersma and Weenink 2013). We controlled the focus survey for embeddedness and focused constituents and the question survey for verb type, subject type, degree of presupposition and for the behavior of «external adverbials» of the type how come (Rizzi 2001).

After performing a quantitative analysis not illustrated here for the sake of brevity, we conclude that, broadly speaking, in Catalan and Spanish the intonational prominence tend to fall on the right-edge of the clause. An exception to this rule is found in Eastern Catalan and Basque Spanish informational focus declaratives, where focus constituent can be moved to the left periphery of the sentence and in Western Catalan and Spanish informational or contrastive focus declaratives in which focus marked prosodically in situ (also called prominence shift in previous studies) is an available strategy. Right dislocation is used to a greater extent in Catalan than in Spanish and that is explained by a difference in information packaging between Catalan and Spanish potentially causing ambiguity that can be resolved by means of prosody (Ziv 1994). Prosody serves to mark the different types of focus. Thus, broad and informational focus declaratives tend to be expressed by means of falling/low contours, whereas the contrastive focus declaratives are characterized by rising-falling contours, that is, a rising pitch accent followed by a low final tone. Rising-falling configurations usually trigger postfocal compression, meaning that the postfocal material is realized in a compressed pitch tonal range.

We found three factors that play an important role in the expression of interrogative modality by means of word order: question type (y/n, wh-, direct or indirect questions), language variety and subject type (nominal, pronominal or usted). An important distinction is made between languages that can present subject-verb inversion in direct questions (VAL_CAT and Spanish) and languages that cannot (Eastern Catalan). In Eastern Catalan the subject is dislocated. An exception to this behavior is exhibited by pronominal subjects ( $1^{\text {st }}$ and $2^{\text {nd }}$ person singular). In this case, we found more instances of preverbal subjects. Formal pronoun usted works as nominal subjects in this respect. We gave an explanation for that based on the lack of matching between the features of the form usted (a second person, formal) and the features in INFL (third person). Our data support the existence of a particular position for this form inside IP. VAL_CAT and CAN_SPA have a preference for preverbal subjects in yes-no questions also when the subject is nominal. Indirect wh-questions are characterized by subject verb inversion in all the varieties, whereas indirect yes-no questions present preverbal subject. We observe no effect of the presupposition about the truth-value of the proposition on the word order. 
Tag questions are an exception in our data since they display declarative word order (although the form usted tends to be inverted).

As for intonation in the expression of interrogative modality, our interpretation is that the absence of syntactic marking (wh-word, subject-verb inversion or subject dislocation) for questions corresponds to a more salient intonational marking. Thus, wh-questions tend to be characterized by falling intonational patterns (although the tonal movement associated to the nuclear syllable can be high or falling/low). Yes-no questions can be classified depending on the nuclear tone (preference for low tones in Catalan and high tones in Spanish) and the final tone (low for language varieties with subject inversion or dislocation, but optionally high for those that do not present syntactic marking in a compulsory way).

\section{References}

Alba, Orlando (1982). «Función del acento en el proceso de elisión de la /s/ en la República Dominicana». In: El Español del Caribe. Dominican Republic: Universidad Católica Madre y Maestra, pp. 17-26.

Bentivoglio, Paola (1983). «Topic continuity and discontinuity in discourse: A study of spoken Latin-American Spanish». In: Givón, Talmy (ed.). Topic continuity in discourse. Amsterdam: John Benjamins, pp. 255-311.

Billmyer, Kristine; Varghese, Manka (2000). «Investigating instrument-based pragmatic variability: Effects of enhancing discourse completion tests. Applied Linguistics 21.4: 517-552.

Blum-Kulka, Shoshana; House, Juliane; Kasper, Gabriele (1989). «Investigating cross-cultural pragmatics: An introductory overview». In: Blum-Kulka, Shoshana; House, Juliane; Kasper, Gabriele (eds.). Cross-cultural pragmatics: Requests and apologies. Norwood, NJ: Ablex, pp. 13-14

Boersma, Paul; Weenink, David (2013). Praat: Doing phonetics by computer [Computer program]. Version 5.3.55, retrieved 2 September 2013 from http://www.praat.org/

Costa, João. (2001). «Marked versus unmarked inversion and Optimality Theory». In: Hulk, Aafke C.; Pollock, Jean-Yves (eds.). Subject inversion and the theory of Universal Grammar. Oxford: OUP, pp. 91-106.

Cruschina, Silvio (2011). «Focalization and word order in Old Italo-Romance». Catalan Journal of Linguistics 10: 92-135.

Cruschina, Silvio (2012). Discourse-related features and functional projections. Oxford: OUP.

D'Introno, Francesco (1989). «Empty and full pronouns in Spanish». Hispanic Linguistics 3: 27-47.

de la Cruz-Pavía, Irene. (2010). «The influence of prosody in the processing of ambiguous RCs: A study with Spanish monolinguals and Basque-Spanish bilinguals from the Basque Country». Interlingüistica XX: 1-12.

de la Cruz-Pavía, Irene; Elordieta, Gorka (submitted). «Prosodic phrasing of relative clauses with two possible antecedents in Spanish: A comparison of Spanish native speakers and L1 Basque bilingual speakers».

de la Mota, Carme (1995). La representación gramatical de la información nueva en el discurso. Universitat Autònoma de Barcelona, doctoral dissertation. 
Demonte, Violeta (1994). Teoría Sintáctica: de las estructuras a la rección. Madrid: Síntesis.

Domínguez, Laura (2002). «Analyzing unambiguous narrow focus in Catalan». In: Ionin, Tania; Ko, Heejeong; Nevins, Andrew (eds.). The Proceedings of the Second Humit Conference. MIT Working Papers in Linguistics 43: 17-34.

Domínguez, Laura (2004). «The effects of phonological cues in the syntax of focus constructions in Spanish». In: Bok-Bennama, Reineke; Hollebrandse, Bart; KampersManhe, Brigitte; Sleeman, Petra (eds.). Romance Languages and Linguistic Theory 2002. Amsterdam: Benjamins, pp. 69-81.

Elordieta, Gorka; Frota, Sonia; Vigário, Marina (2005). «Subjects, objects and intonational phrasing in Spanish and Portuguese». Studia Linguistica 59.2-3: 110-143.

Elordieta, Gorka; Irurtzun Aritz (2012). «Movimiento y prosodia». In: Brucart, Josep Maria; Gallego, Ángel (eds.). El movimiento de constituyentes. Madrid: Visor Libros, pp. 213-234.

Enríquez, Emilia. (1984). El pronombre personal sujeto en la lengua española hablada en Madrid. Madrid: CSIC.

Escandell-Vidal, Victoria. (1999). «Los enunciados interrogativos. Aspectos semánticos y pragmáticos». In: Bosque, Ignacio; Demonte, Violeta (dirs.), Gramática Descriptiva de la Lengua Española. Madrid: Espasa Calpe, cap. 61, pp. 3929-3991.

Estebas-Vilaplana, Eva (2003a). «Phonetic and phonological properties of the final pitch accent in Catalan declaratives». In: Metouchi, Amina; Ferré, Gaëlle (eds.). Proceedings of the international conference on prosodic interfaces. Université de Nantes, pp. 35-40.

Estebas-Vilaplana, Eva (2003b). «The modelling of prenuclear accents in Central Catalan declaratives». Catalan Journal of Linguistics 2: 97-114.

Estebas-Vilaplana, Eva (2000). The use and realisation of accentual focus in Central Catalan with a comparison to English. University College London, doctoral dissertation.

Face, Timothy L. (2001). «Focus and early peak alignment in Spanish intonation». Probus 13: 223-246.

Face, Timothy L. (2002). «Local intonational marking of Spanish contrastive focus». Probus 14: 71-92.

Face, Timothy L. (2004). «The intonation of absolute interrogatives in Castilian Spanish». Southwest Journal of Linguistics 23.2: 65-79.

Face. Timothy L.; D’Imperio, Mariapaola (2005). «Reconsidering a focal typology: Evidence from Spanish and Italian». Italian Journal of Linguistics 17: 271-289.

Félix-Brasdefer, César (2010). «Data collection methods in speech act performance: DCTs, role plays, and verbal reports». In: Martínez-Flor, Alicia; Usó-Juan, Esther (eds.). Speech act performance: Theoretical, empirical, and methodological issues. Amsterdam/Philadelphia: John Benjamins, pp. 41-56.

Fernández Ramírez, Salvador (1951). Gramática española. Los sonidos, el nombre y el pronombre. Madrid: Revista de Occidente.

Fernández Soriano, Olga (1993). «Sobre el orden de palabras en español». Dicenda 11: 113-152.

Fernández Soriano, Olga (1999). «El pronombre personal. Formas y distribución. Pronombres átonos y tónicos». In: Bosque, Ignacio; Demonte, Violeta (dirs.). Gramática descriptiva de la lengua española. Madrid: Espasa Calpe, cap. 32, pp. 1209-1275. 
Gabriel, Christoph (2006). «Focal pitch accents and subject positions in Spanish: Comparing close-to-standard varieties and Argentinean Porteño». In: Hoffman Rüdiger; Mixdorff, Hansjörg (eds). Speech prosody 2006. Dresden: TUDpress.

Gabriel, Christoph (2007). Fokus im Spannungsfeld von Phonologie und Syntax. Eine Studie zum Spanischen. Frankfurt: Vervuert.

Gabriel, Cristoph (2010). «On focus, prosody, and word order in Argentinean Spanish: a minimalist OT account». ReVEL. Revista Virtual de Estudos da Linguagem, Special issue 4 «Optimality theoretic Syntax»: 183-222.

Gómez Seibane, Sara. (2012). «Contacto de lenguas y orden de palabras: OV/VO en el español del País Vasco». Lingüística Española Actual 34.1: 115-136.

Grice, Martine; Savino, Michelina; Refice, Mario (1997). «The intonation of questions in Bari Italian: Do speakers replicate their spontaneous speech when reading?». Phonus 3: 1-7.

Groos, Anneke; Bok-Bennema, Reineke (1986). «The structure of the sentence in Spanish». In: Bordelois, Ivonne; Contreras, Heles; Zagona, Karen (eds.). Generative studies in Spanish syntax. Dordrecht: Foris, pp. 67-80.

Gutiérrez-Bravo, Rodrigo (2005). «Subject inversion in Spanish relative clauses. A Case of prosody-induced word order variation without narrow focus». In: Geerts, Twan; Jacobs, Haike (eds.). Romance Languages and Linguistic Theory 2003. Amsterdam: John Benjamins.

Gutiérrez-Bravo, Rodrigo (2006) Structural markedness and syntactic structure. A study of word order and the left periphery in Mexican Spanish. New York: Routledge.

Gutiérrez-Bravo, Rodrigo (2002). «Focus, word order variation and intonation in Spanish and English». In: Wiltshire, Caroline R.; Camps, Joaquim (eds.). Romance phonology and variation. Amsterdam: John Benjamins, pp. 39-53.

Hernanz, Maria Lluïsa (2002). «L’oració». In: Solà, Joan; Lloret, Maria-Rosa; Mascaró, Joan; Pérez-Saldanya, Manel (dirs.). Gramàtica del català contemporani. Barcelona: Editorial Empúries, pp. 993-1073.

Hernanz, Maria Lluïsa; Brucart, Josep Maria. (1987). La Sintaxis (1). Barcelona: Crítica.

Hirschberg, Julia; Avesani, Cinzia. (2000). «Prosodic disambiguation in English and Italian». In: Botinis, Antonis (ed.). Intonation. Dordrecht: Kluwer Academic, pp. 87-95.

Hochberg, Judith G. (1986). «Functional compensation for /s/ deletion in Puerto Rican Spanish». Language 62: 891-894.

Hualde, José Ignacio (2002). «Intonation in Spanish and the other Ibero-Romance Languages: Overview and Status Quaestionis». In: Wiltshire, Caroline R.; Camps, Joaquim (eds.). Romance phonology and variation. Amsterdam: Benjamins, pp. 101-115.

Hualde, José Ignacio. (2005). The sounds of Spanish. Cambridge University Press.

Hualde, José Ignacio; Prieto, Pilar (in press, 2014). «Intonational variation in Spanish: European and American varieties». In: Frota, Sonia; Prieto, Pilar (eds.). Intonational variation in Romance. Oxford: OUP.

Kany, Charles E. (1951). American Spanish syntax. Chicago: University of Chicago Press.

Keniston, Hayward (1937). The syntax of Castillian prose. The sixteenth century. Chicago: University of Chicago Press. 
Lipski, John M. John M. Lipski. March 2013. < http://www.personal.psu.edu/jml34/> López, Luis (2003). «Steps for a well-adjusted dislocation». Studia Linguistica 57.3: 193-231.

Prieto, Pilar (in press, 2014). «The Intonational Phonology of Catalan». In: Jun, Sun-Ah (ed.). Prosodic Typology 2. Oxford: OUP, pp. 43-80.

Prieto, Pilar; Borràs-Comes, Joan; Cabré, Teresa; Crespo-Sendra, Verònica; Mascaró, Ignasi; Roseano, Paolo; Sichel-Bazin, Rafèu, Vanrell, Maria del Mar (in press, 2014). «Intonational phonology of Catalan and its dialectal varieties». In: Frota, Sonia; Prieto, Pilar (eds.). Intonational variation in Romance. Oxford: OUP.

Prieto, Pilar; Cabré, Teresa (eds.) (2007-2012). Atles interactiu de l'entonació del català. <http://prosodia.upf.edu/atlesentonacio/>

Prieto, Pilar; Rigau, Gemma (2007). «The syntax-prosody interface: Catalan interrogative sentences headed by que». Journal of Portuguese Linguistics 6.2: 29-59.

Ranson, Diana L. (1991). «Person marking in the wake of /s/ deletion in Andalusian Spanish». Language Variation and Change 3: 133-152.

Rizzi, Luigi (2001). «On the position «Int(errogative)» in the left periphery of the clause». In: Cinque, Guglielmo; Salvi, Giampaolo (eds.). Current studies in Italian syntax. Essays offered to Lorenzo Renzi. Amsterdam: Elsevier, pp. 287-296.

Roseano, Paolo; Vanrell, Maria del Mar; Prieto, Pilar (in press, 2014). «Intonational phonology of Friulian and its dialects». In: Frota, Sonia; Prieto, Pilar (eds.). Intonational Variation in Romance. Oxford University Press.

Rosengren, Paul (1994). Presencia y ausencia de los pronombres personales de sujeto en el español moderno. Acta Universitaria Gothoburguensis, Romanica Gothoburguensia XIV.

Rosselló, Joana (2002). «A minimalist approach to the null subject parameter». Catalan Working Papers in Linguistics 8: 97-128.

Samek-Lodovici, Vieri (2001). «Crosslinguistic typologies in Optimality Theory». In: Legendre, Géraldine; Grimshaw, Jane; Vikner, Jane (eds.). Optimality-Theoretic Syntax. Cambridge, MA: MIT Press, pp. 315-354.

Samek-Lodovici, Vieri (2005). «Prosody syntax interaction in the expression of focus». Natural Language and Linguistic Theory 23: 687-755.

Samek-Lodovici, Vieri (2006). «Optimality Theory and the Minimalist Program». Linguistics in Potsdam 25: 77-97.

Sánchez López, Cristina (1993). La cuantificación flotante y estructuras conexas. Universidad Complutense de Madrid, doctoral dissertation.

Savino, Michelina (2012). «The intonation of polar questions in Italian: Where is the rise?». Journal of the International Phonetic Association 42.1: 23-48.

Sedano, Mercedes (2006). «Sobre la dislocación a la derecha en español». Lingua Americana 18: 59-73.

Silva-Corvalán, Carmen (1982). «Subject expression and placement in MexicanAmerican Spanish». In: Amastae, Jon; Elías-Olivares, Lucía (eds.). Spanish in the United States: Sociolinguistic aspects. Cambridge: CUP, pp. 93-120.

Simonet, Miquel (2009). «Nuclear pitch accents in Majorcan Catalan declaratives: Phonetics, phonology, diachrony». Studies in Hispanic and Lusophone Linguistics 2: 77-115.

Simonet, Miquel (2010). «A contrastive study of Catalan and Spanish declarative intonation: Focus on Majorcan dialects». Probus 22: 117-148. 
Simonet, Miquel (2011). «Intonational convergence in language contact: Utterancefinal contours in Catalan-Spanish bilinguals». Journal of the International Phonetic Association 41: 185-205.

Solà, Joan (1990). «L'ordre dels mots en català. Notes pràctiques». In: Solà, Joan (ed.). Lingüística i normativa. Barcelona: Empúries, pp. 91-124.

Sosa, Juan Manuel. (1999). La entonación del español. Madrid: Cátedra.

Suñer, Margarita (1982). Syntax and semantics of Spanish. Washington: Georgetown University Press.

Urrutia, Hernán (1995). «Morphosyntactic features in the Spanish of the Basque Country». In: Silva-Corvalán, Carmen (ed.). Spanish in four continents. Washington D.C.: Georgetown University, pp. 243-259.

Vallduví, Enric (1991). «The role of plasticity in the association of focus and prominence». Proceedings of the Eastern States Conference on Linguistics (ESCOL) 7: 295-306.

Vallduví, Enric (1994). «Detachment in Catalan and information packaging». Journal of Pragmatics 22: 573-601.

Vanrell, Maria del Mar; Ballone, Francesc; Schirru, Carlo; Prieto, Pilar (in press, 2014). «Sardinian intonational phonology: Logudorese and Campidanese varieties». In: Frota, Sonia; Prieto, Pilar (eds.). Intonational variation in Romance. Oxford: OUP.

Vanrell, Maria del Mar; Stella, Antonio; Gili Fivela, Barbara; Prieto, Pilar (2011). «Prosodic cues for the recognition of contrastive focus». In: Gili Fivela, Barbara; Stella, Antonio; Garrapa, Luigina; Grimaldi, Mirko (eds.). Contesto comunicativo e variabilità nella produzione e percezione della lingua. Atti del VII Convegno Nazionale AISV. Roma: Bulzoni, pp. 224-235.

Vanrell, Maria del Mar; Stella, Antonio; Gili Fivela, Barbara; Prieto, Pilar (2013). «Prosodic manifestations of the Effort Code in Catalan, Italian and Spanish contrastive focus». Journal of the International Phonetic Association 43.2: 195-220.

Villalba, Xavier (2011). «A quantitative comparative study of right-dislocation in Catalan and Spanish». Journal of Pragmatics 43: 1946-1961.

$\mathrm{Xu}$, Yi; Chen, Szu-Wei; Bei, Wang (2012). «Prosodic focus with and without postfocus compression (PFC): A typological divide within the same language family?». The Linguistic Review 29: 131-147.

$\mathrm{Xu}, \mathrm{Yi}$ (1999). «Effects of tone and focus on the formation and alignment of F0 contours». Journal of Phonetics 27: 55-105.

Ziv, Yael (1994). «Left and right dislocations: discourse functions and anaphora». Journal of Pragmatics 22: 629-664.

Zubizarreta, Maria Luisa (1998). Prosody, focus, and word order. Cambridge: MIT Press. 